\title{
Corporate Governance and Financial Fraud of Wirecard
}

\author{
Hoje Jo, Annie Hsu, Rosamaria Llanos-Popolizio, and Jorge Vergara-Vega
}

\section{ABSTRACT}

\begin{abstract}
This paper examines the antecedents and consequences of the collapse of Wirecard AG, in June 2020, the "German Enron." Specifically, we investigate how the Wirecard's ineffective corporate governance under the German's financial regulatory system fails to serve their stakeholders, and how its management's unethical behavior of earnings manipulation contribute to significant financial collapse for the company, and lead to the destruction of shareholders' value. This paper examines how the internal and external governance and monitoring mechanisms failed to uncover the vast fraud at the German payments group at a much earlier stage. Furthermore, we find evidence consistent with the hypothesis that the continuous pressure of meeting or exceeding consensus on earnings estimates, management's performance compensation based on the growth of Wirecard's stock price, and the lack of proper supervision from the board of directors ultimately create the opportunities for management to manipulate earnings without being uncovered for several years. Such course of action has caused significant financial corporate misconduct for Wirecard and led to the destruction of firm value.
\end{abstract}

Keywords: Corporate governance, earnings manipulation, corporate misconduct, financial scandal, German financial regulatory system, the German Enron, Wirecard.
Submitted: January 22, 2021

Published: March 25, 2021

ISSN: $2507-1076$

DOI: $10.24018 / \mathrm{ejbmr} .2021 .6 .2 .708$

\section{Hoje Jo*}

$\mathrm{PhD}$ in finance, University of Florida, USA.

(e-mail: hjo@scu.edu)

Annie Hsu

MBA in finance, Santa Clara University, USA.

(e-mail: achsu@scu.edu)

Rosamaria Llanos-Popolizio

MBA in finance, Santa Clara University, USA.

(e-mail: rllanospopolizio@ ${ }^{\circledR}$ scu.edu)

Jorge Vergara-Vega

MBA in finance, Santa Clara University, USA.

(e-mail: jvergaravega@ ${ }^{@}$ scu.edu)

*Corresponding Author

\section{INTRODUCTION}

Wirecard AG, Wirecard or the Company, (ticker: WDI Germany), one of the Germany's leading financial technology companies in providing digital platforms for financial commerce, filed for insolvency in June 2020 after revealing $€ 1.9$ billion of cash on its balance sheet had gone missing and shortly after its Chief Executive Officer (CEO) got arrested on charges related to market manipulation and false accounting. In September 2018, Wirecard became the fastest growing fintech firm listing in Germany's stock exchange, and outed Germany's second largest lender, Commerzbank AG. However, on June 25, 2020, Wirecard became the first sitting member of Germany's blue-chip DAX index to file for court protection from creditors at a Munich court. Since then, the Company's share price has plunged over $90 \%$, falling from $€ 104.50$ on June 17,2020 to $€ 1.28$ on June 26,2020 . This corporate scandal has exposed certain financial flaws in Germany's regulatory environment and has posed numerous questions for the European fintech industry. The collapse of Wirecard has also prompted members of the German Parliament to conduct an investigation in the Company (now being called "the German Enron") and to examine the German regulations over its financial system. The European Commission has also demanded its market watchdog to investigate Germany's financial regulator, BaFin (the Federal Financial Supervisory Authority in Germany) over the fall of Wirecard.
The purpose of this paper is to examine Wirecard's corporate governance (CG) and understand how they failed to prevent the financial fraud from taking place. This paper further examines Wirecard's financial misconduct which significantly impacted shareholders' value and resulted in substantial financial losses. This paper starts with a synopsis of the Company and its financial scandal. Then, it investigates the causes behind Wirecard's financial scandal as a way to gain additional insights on corporate scandals in international countries. Following, this paper examines Wirecard's CG structure and explains how the internal and external monitoring mechanisms failed to serve its shareholders, and how its management's unethical behavior to manipulate earnings contributed to the destruction of shareholders' value. Lastly, this paper further examines the challenges that fintech poses to the financial regulation in Germany and determines if it needs to be reformed in order to reduce accounting malpractice, strengthen the CG system, and as result enhance Germany's economy.

\section{HYPOTHESES}

Strong CG is crucial to create a corporate culture of transparency, accountability, and disclosure. Jo and Harjoto [1] suggest that the internal board of directors and external stakeholders including government regulators, shareholders, creditors, auditors, and analysts play an important role in the $\mathrm{CG}$ and monitoring mechanisms of a business organization to oversee the action of management and resolve the conflicts of 
interests between shareholders and management to maximize the long-term value of the company. Jensen [2] and Miller [3] further maintain that the collapse of many multinational public corporations, including the energy giant Enron Corp., highlighted the importance of information transparency and managerial incentives as they typically limit the effectiveness of $\mathrm{CG}$ in public corporations. As it is difficult for the board of directors to directly observe the actions of managers who act in the interest of shareholders, managers' compensation is often directly related to the performance of the company. However, this arrangement could potentially create an incentive for management to manipulate earnings [1], [4]-[6]. Jo, Kim, and Park [5] suggest that financial managers have an incentive to manipulate earnings around seasoned equity offering (SEO) when the quality of underwriter is sub-par, while Jo and Kim [6] find that managers have an incentive to inflate earnings around SEO and abruptly increase disclosure frequency when they want to increase the SEO offer price. A corporate culture within Wirecard of always meeting analysts' earnings expectations and stakeholders' interests ultimately created the incentive to manipulate earnings results.

In the case of Wirecard, management manipulated its numbers on the financial statements and hid the Company's losses from being shared with the public in an effort to maintain the growth of the stock price. German regulators have placed high reliance on the idea of self-regulation and on the relationship of stock ownership by management, and reliability on a company's trustworthiness. "Documents show that the Federal Financial Supervisory Authority, or Bafin, saw Wirecard's former CEO, now under criminal investigation, as more trustworthy than his critics because he bought a large chunk of shares in the Company at a key moment" [7]. German regulators failed to realize Wirecard's insolvency because no one trustworthy like regulators and external auditors raised any flags, even when in suspicions of fraud.

Additionally, studies found that an effective CG "realigns management's incentives to maximize shareholders' value instead of to manipulate earnings for their own personal benefit" [4]. It is necessary to examine the structure of the Supervisory Board of Wirecard to determine their contribution to the fallout of the Company, and why CG of Wirecard including its internal Supervisory Board and external stakeholders have been ineffective to oversee accounting malpractices and prevent conflicts of interest between management and shareholders.

H1: The CG of Wirecard has been ineffective to oversee accounting malpractices.

The Supervisory Board is a key component of the CG structure and their primary role is to ensure management makes decisions in the long-term interest of shareholders. In the case of Wirecard, several executives of the Company used the "round tripping" scheme and fictitious third-party acquirers to manipulate earnings since 2015. During these years, Wirecard grew from a niche payments service to a top tier German publicly traded company in the exclusive DAX 30 index. Wirecard's accounting practices have been called into questions from journalists and short sellers in 2008, 2015, 2016, and 2018. Despite the increasing questions over Wirecard's accounting practices during these years, the
Supervisory Board had breached its duty of care as they failed to conduct their independent internal investigation of the allegations relating to Wirecard's accounting malpractices and also failed to prevent management from wrongdoing. Although it is in the interest of shareholders and management to maximize the company's intrinsic value in the long-term, it is not necessarily true for short-term investors who would prefer management to focus on actions increasing the current stock price.

As further described under inflation of revenue and profit, Wirecard used the "round tripping" fraud scheme to artificially overstate revenue and cash over the course of several years. Management was under significant pressure for meeting Street's expectations, which were developed based on the significant growth experienced by Wirecard over the past years (refer to Company's financial highlights).

One of the most widely cited papers that investigates the effect of executive compensation plans on accrual decisions and accounting choice is Healy [8]. Healy hypothesizes that a manager has an economic incentive to manipulate earnings in order to increase their cash compensation. Healy [8] proposes the following hypotheses:

a. If earnings before discretionary accruals are less than the manager's lower bound threshold, the manager has an incentive to select income-decreasing discretionary accruals.

b. If earnings before discretionary accruals exceed the manager's lower bound threshold, but not the upper bound, the manager has an incentive to select incomeincreasing discretionary accruals.

c. If the bonus plan contains an upper bound and earnings before discretionary accruals exceed that limit, the manager has an incentive to select income-decreasing discretionary accruals.

Based on Healy [8] and an incentive for management to manipulate earnings [1], [4]-[6] as management has access to information not available to shareholders and the decisionmaking process is substantially under their control, we postulate that under a corporate culture of always meeting Street's expectations would develop a strong incentive to manipulate earnings when financial results become unfavorable.

When the main focus becomes showing artificial business growth through accounting manipulation and fraud instead of the acquisition of "real" customers generating revenue and cash collections, a fraud scheme begins to develop and grow over time until it becomes unsustainable, and it is ultimately uncovered. At that point, investors run the risk of losing all their investment.

H2: Accounting manipulation leads to substantial stock price decline.

As shown under compensation structure, the Management Board is highly compensated. The compensation of the Management Board consists of a performance and nonperformance compensation structure. In fiscal 2018, the performance compensation comprised $35 \%$ of the total compensation. The performance compensation consisted of a Multi-year Variable Remuneration (MVR) and a Single-year Variable Remuneration (SVR). Both metrics considered a stock price growth of $15 \%$ and an EBITDA growth of $20 \%$. 
For the board of directors it is impossible to perfectly observe the actions of management. In order to ensure management acts in the best interest of the shareholders, their compensation is closely tied to the performance of the company. Corporate trends have seen dramatic rises in links between management compensation and corporate performance, such that it reflects the mainstream nowadays.
Accordingly, management's interests are aligned with the shareholders' interests through a threat of redundancy, which raises the concern of losing their jobs if they do not maximize shareholders' value. Fig. 1 summarizes the incentive to manipulate earnings and misalignment of interests between management and shareholders:

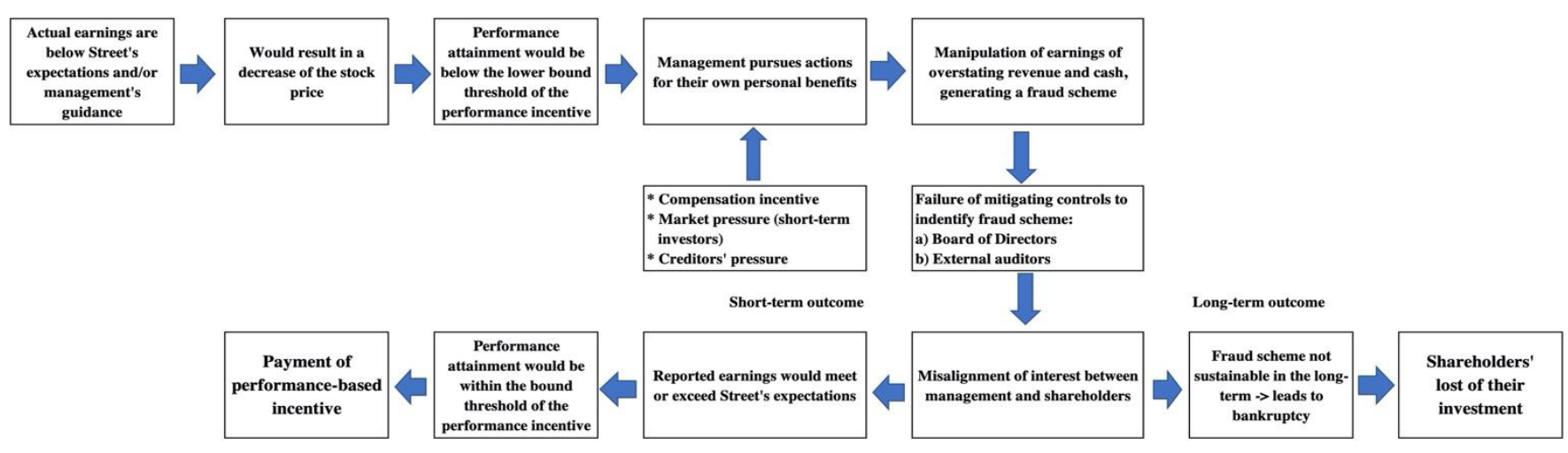

Fig. 1. Summary of the incentive to manipulate earnings.

It is not clear how management was planning to undo the fraud scheme. We are under the assumption that it was a temporary solution until management figured out how to accelerate the organic growth of revenue through the addition of real new customers, upsell of services, and/or through business acquisitions. Wirecard's fraud scheme was not sustainable in the long run, at some point it was going to be uncovered.

The continuous pressure of meeting or exceeding consensus on earnings and management's performance compensation based on the growth of Wirecard's stock price led management to grow sales and cash artificially through a fraud scheme.

\section{WIRECARD COMPANY BACKGROUND}

Wirecard was originally founded in 1999 as a payment processor that supported mainly porn and gambling websites collecting credit card payments [9]. In 2002, after a few years of operation, the Company needed a refresh and elected Markus Braun as its CEO. His first directive was to merge Wirecard with Electronic Business Systems, another German fintech company. In 2005, Wirecard joined the Frankfurt stock market, and in 2006 it moved into banking with the purchase of XCOM, becoming Wirecard Bank. Overtime, Wirecard developed three different business models worldwide.

Wirecard's Original Business Model: Payment Processing Services. Under this model, "Wirecard provides infrastructure and services for online payments," [10] processing worldwide by charging a fee per online payment transaction: "When a customer buys something from a merchant, its bank transfers the money (often via credit card companies) to the so called acquirer (Wirecard) which then transfers the money with a time lag to the merchant. The acting of an acquirer is necessary as it provides insurance for e.g., the credit card companies against the merchant not delivering the goods, or similar cases. The acquirer optimizes its risk management by delayed payments and staggered payments" [10]. This model is based on negative-workingcapital business only available to Wirecard as a direct result of its banking license as shown in Fig. 2.

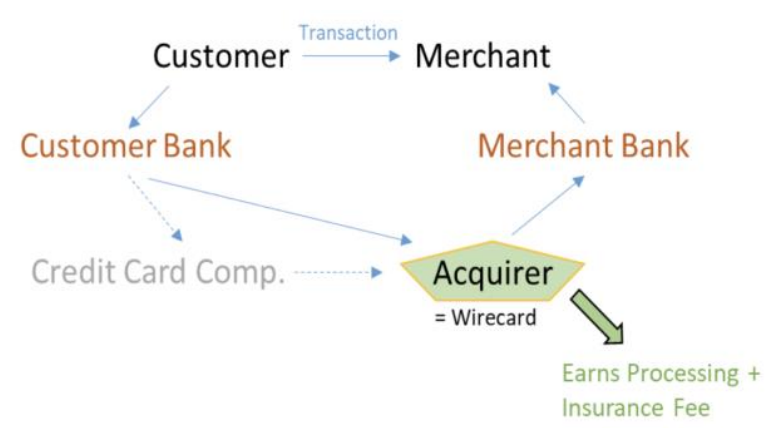

Fig. 2. Negative-working-capital business model Source: Meitner [10]

Wirecard's Second Business Model: Third-Party Acquirer (TPA). Under this model, Wirecard partners up with a bank in the region where it wants to do business, uses this partner's banking license, pays them a commission fee, provides security deposits acting as a guardian of the transaction (customer-merchant) ensuring "that the TPA is not running into danger arising from customer merchant transaction" [10].

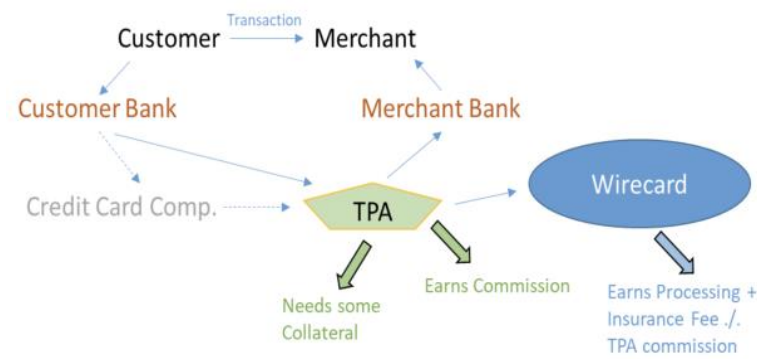

Fig. 3. Wirecard's second business model: Third-Party Acquirer (TPA). Source: Meitner [10].

Wirecard's Third Business Model: Merchant Cash Advances (MCA). Also known as digital lending, it is less a 
business model and more a value-added service. Wirecard (either directly or via TPA) offers "some sort of earlysettlement of the transaction to the merchant avoiding the delayed payments. This service can be understood as some sort of working capital financing to the merchants" [10].

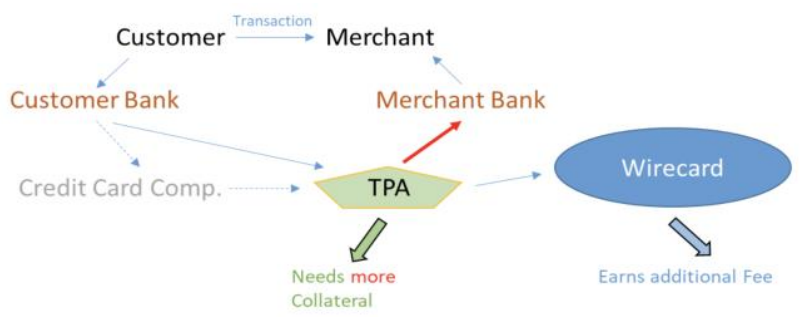

Fig. 4. Wirecard's Third Business Model: Merchant Cash Advances (MCA). Source: Meitner [10].

In these untraditional hybrid business models of Wirecard - banking and non-banking operations - what "makes its accounts harder to compare with peers and helps persuade investors to rely on the Company's adjusted versions of financial statements" [11]. It is believed that the transactions under these hybrid models is where most of the financial manipulation took place: "Wirecard has to provide in these two transactions security deposits. It usually does so on escrow accounts and via trustees. But one consequence of this is that now this cash is sitting somewhere abroad" [10].

Wirecard claims to be one of Europe's leading payments companies processing $\$ 140.0$ billion in transactions a year, more than any other German bank [12]. Its rapid expansion into Asia was believed, by its investors, to have allowed the company to gain an even greater share of the online payment market. However, Wirecard's revenue transactions with certain TPA between 2016 and 2018 have been investigated by its prosecutors and external auditors for existence. In the KPMG LLP (KPMG)'s 2020 report concerning the independent special investigation of Wirecard's third party acquiring business with third party acquiring partners, KPMG disclosed that they could not really "evidence the existence or concrete amount of Wirecard's revenues" [10] for the investigation period from 2016 to 2018 as "contracts between the TPA partners and the merchants as well as account statements and bank confirmations for escrow accounts had not been made available" [11].

In June 2020, following the Philippine banks' (BDO Unibank Inc. and Bank of the Philippine Islands) confirmations to Ernst \& Young LLP (EY), Wirecard's external auditors, seemed to indicate that $€ 1.9$ billion was spurious. Wirecard admitted that $€ 1.9$ billion supposedly held in trustee accounts by overseas TPA partners probably never existed [10]. Wirecard's CEO, former Chief Financial Officer (CFO) and Chief Accounting Officer (CAO) were arrested on suspicion of false accounting and market manipulation. The Company's former Management Board is also under investigation. At the end of June 2020, Wirecard filed for insolvency as its share price dropped from a high of $€ 195.75$ in 2018 to $€ 1.28$ at the end of June 2020 .

\section{A. Management Board}

The Management Board of Wirecard consisted of four members. Table I lists the members of the Management Board before filing for insolvency.

\begin{tabular}{ll}
\multicolumn{2}{c}{ TABLE I: MANAGEMENT BOARD BEFORE FILING FOR INSOLVENCY } \\
\hline Name & Title \\
\hline Dr. Markis Braun & Chief Executive Officer \\
Alexander von Knoop & Chief Financial Officer, effective \\
& January 1, 2018 \\
Burkhard Ley (1) & Former Chief Financial Officer, \\
& from January 2006 to December \\
& 2017 \\
Jan Marsalek & Chief Operating Officer \\
Susanne Steidl & Chief Product Officer
\end{tabular}

(1) Burkhard Ley had been a key member of the Management Board and had direct knowledge of Wirecard's financial transactions. He left the Management Board in December 2017.

Source: Wirecard AG 2018 Annual Report [19].

\section{B. Financial Highlights}

As of July 31, 2020, based on Wirecard's corporate website, the Company had over 5,800 employees globally and operated in 26 locations around the world. The following table summarizes Wirecard's key financial metrics and growth over the past five fiscal years:

TABLE II: WIRECARD'S KEY FINANCIAL METRICS

\begin{tabular}{|c|c|c|c|c|c|c|c|}
\hline Financial Metrics & $6 \mathrm{M}-2019$ & $6 \mathrm{M}-2018$ & 2018 & 2017 & 2016 & 2015 & 2014 \\
\hline \multicolumn{8}{|c|}{ (in millions, except for EPS and percentages) } \\
\hline Revenue & $€ 1,210$ & $€ 885$ & $€ 2,016$ & $€ 1,489$ & $€ 1,028$ & $€ 771$ & $€ 601$ \\
\hline Growth \% & $37 \%$ & & $35 \%$ & $45 \%$ & $33 \%$ & $28 \%$ & \\
\hline Net income & $€ 238$ & $€ 158$ & $€ 347$ & $€ 256$ & $€ 267$ & $€ 143$ & $€ 108$ \\
\hline Growth \% & $51 \%$ & & $36 \%$ & $-4 \%$ & $87 \%$ & $32 \%$ & \\
\hline EPS, fully diluted & $€ 1.92$ & $€ 1.27$ & $€ 2.81$ & $€ 2.07$ & $€ 2.16$ & $€ 1.16$ & $€ 0.89$ \\
\hline Growth \% & $51 \%$ & & $36 \%$ & $-4 \%$ & $86 \%$ & $30 \%$ & \\
\hline EBITDA & $€ 342$ & $€ 252$ & $€ 583$ & $€ 404$ & $€ 320$ & $€ 232$ & $€ 177$ \\
\hline Growth $\%$ & $36 \%$ & & $44 \%$ & $26 \%$ & $38 \%$ & $31 \%$ & \\
\hline $\begin{array}{l}\text { Cash flows from } \\
\text { operations }\end{array}$ & $€ 178$ & $€ 224$ & $€ 738$ & $€ 553$ & $€ 288$ & $€ 176$ & $€ 127$ \\
\hline Growth $\%$ & $-21 \%$ & & $33 \%$ & $92 \%$ & $64 \%$ & $39 \%$ & \\
\hline $\begin{array}{c}\text { Cash and } \mathrm{S} / \mathrm{T} \\
\text { investments }\end{array}$ & $€ 3,564$ & $(*)$ & $€ 2,859$ & $€ 2,010$ & $€ 1,489$ & $€ 1,184$ & $€ 784$ \\
\hline Growth $\%$ & $(*)$ & & $42 \%$ & $35 \%$ & $26 \%$ & $51 \%$ & \\
\hline Working capital & $€ 222$ & $(*)$ & $€ 1,586$ & $€ 775$ & $€ 760$ & $€ 483$ & $€ 408$ \\
\hline Growth \% & $(*)$ & & $105 \%$ & $2 \%$ & $57 \%$ & $18 \%$ & \\
\hline Debt & $€ 1,718$ & $(*)$ & $€ 1,510$ & $€ 1,093$ & $€ 614$ & $€ 383$ & $€ 105$ \\
\hline Growth \% & $(*)$ & & $38 \%$ & $78 \%$ & $60 \%$ & $265 \%$ & \\
\hline
\end{tabular}

(*) Information not available.

Source: Wirecard AG 2018 Annual Report [19]. Wirecard AG Half Year Financial Report as of June 30, 2019 [20] 
Based on the historical consolidated financial statement information, Wirecard revealed a healthy financial growth over the five-year period that ended on December 31, 2018. For example:

a. Revenue grew $28 \%, 33 \%, 45 \%$, and $35 \%$ in fiscal 2015 , 2016,2017 , and 2018, respectively, and $37 \%$ for the six months ended June 30, 2019.

b. EBITDA grew $31 \%, 38 \%, 26 \%$, and $44 \%$ in fiscal 2015 , 2016, 2017, and 2018, respectively, and $36 \%$ for the six months ended June 30, 2019.

c. Cash flows from operations grew $39 \%, 64 \%, 92 \%$, and $33 \%$ in fiscal 2015, 2016, 2017, and 2018, respectively, and decreased $21 \%$ for the six months ended June 30, 2019.

d. Cash and short-term investments, which is an indication of the Company's liquidity, grew $51 \%, 26 \%, 35 \%$, and $42 \%$ in fiscal 2015, 2016, 2017, and 2018, respectively.

As shown in Fig. 5 below, there is a high correlation between the operational growth shown by the financial information and Wirecard's stock price, which reached the highest price of $€ 195.75$ on September 3, 2018 and dropped sharply to $€ 1.93$ on July 31,2020 , as a result of Wirecard filing for insolvency at the end of June 2020.

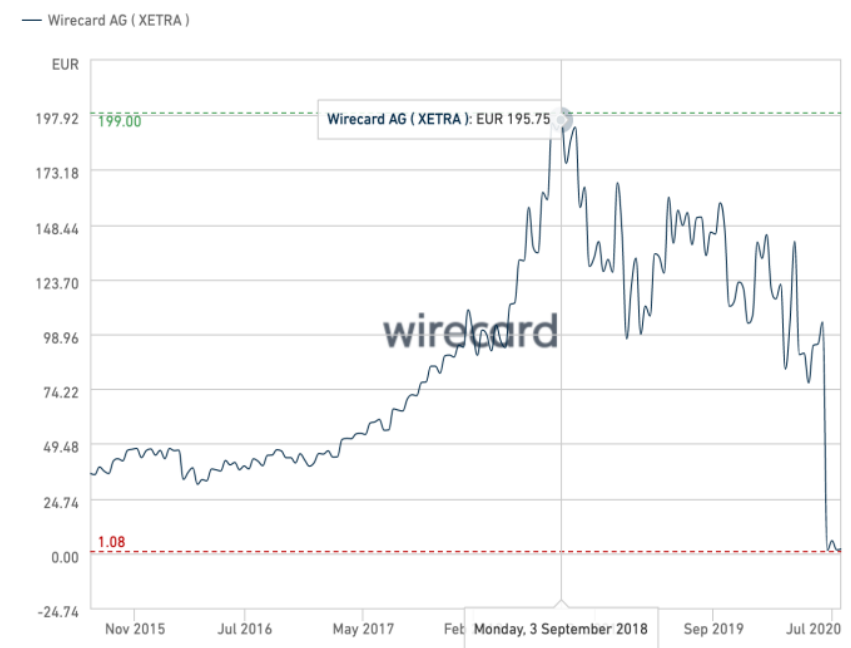

Fig. 5. Wirecard's Stock Price over Time. Source: Wirecard's corporate website, Investor Relations.

\section{Third-Party Acquirers}

Beginning in 2015, several Wirecard's executives, including Burkhard Ley, former CFO, used independent third-party acquirers to expand Wirecard's reach into new markets in Asia (where it did not have a business license) to inflate revenue and cash balances, and make the Company's loss-making business to look profitable. A significant amount of Wirecard's business was outsourced to third party payment processing partners who paid Wirecard a commission [9]. Additionally, the arrangements with Singapore-based Senjo Group and other similar companies in Dubai and the Philippines generated more than half of Wirecard's revenue and contributed $95 \%$ of its earnings in recent years [12].

Wirecard's relationships with third-party acquirers were questionable. Through a review of an email between Jan Marsalek, Chief Operating Officer (COO), and Edo Kurniawan, former Head of Accounting for Asia-Pacific Operations, dated December 29, 2015, a request to the Senjo
Group to fill a shortfall in the Company's 2015 operating profit in Indonesia was uncovered as part of a fraud investigation. Employees at Senjo Group and other payments companies arranged $€ 3.3$ million software license transactions over the first few months of 2016, backdating the contracts and invoices to 2015 [12].

Based on the Wirecard's corporate records in Singapore, Senjo Group is partly owned by Richard Willett, who lives on a ranch in Montana and could not be reached for investigations [12]. Furthermore, the location of an international payments business in the Philippines is surprisingly found to be the house of a retired seaman and his family [12].

\section{Inflation of Revenue and Profit}

Wirecard used the "round tripping" scheme in the Singapore office over several years to deceive its external auditors and create false perceptions of its business revenue. Edo Kurniawan, former Head of Accounting for Asia-Pacific Operations, taught his group in Singapore how to alter the accounting records, or "cook the books," using the "round tripping" technique in which "a lump of money would leave the bank Wirecard owns in Germany, show its face on the balance sheet of a dormant subsidiary in Hong Kong, depart to sit momentarily in the books of an external "customer", then travel back to Wirecard in India, where it would look to local auditors like legitimate business revenue" [16]. In October 2019, the Financial Times (FT) further reported that profits at Wirecard Dubai and Dublin were fraudulently overstated from customers that did not exist. [13].

The inflated revenue and cash balance through fake transactions not only allowed Wirecard to borrow $€ 3.2$ billion from banks and investors but also enabled it to obtain bank license from the Hong Kong Monetary Authority to issue prepaid bank cards to consumers and companies in China [14]. When $€ 1.9$ billion of cash balance was found missing by EY, as a result of inflating the Company's revenue and profit, Wirecard was likely to default on its bank loan and became Germany's biggest accounting scandal. Table III provides the timeline for Wirecard's accounting fraud and insolvency. Fig. 6 provides how Wirecard's stock price responded to its scandal.

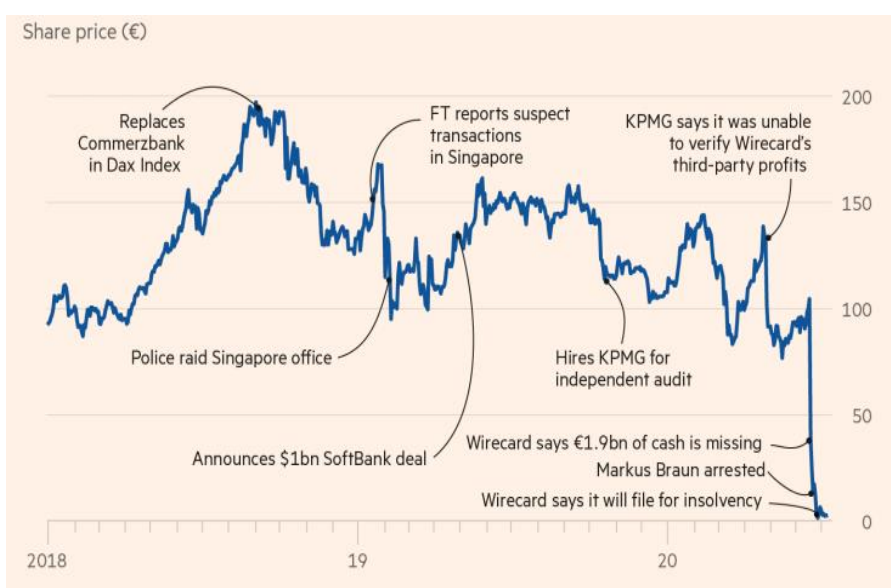

Fig. 6. Wirecard's stock price and scandal. Source: McCrum [13]. 


\section{Head of a German shareholder association attacks Wirecard's balance sheet irregularities. EY becomes the main auditors for A. Supervisory Board Structure}

Wirecard. The German authorities prosecute two persons in connection with the attack due to insufficient disclosure of holding Wirecard's stock.

2010 Jan Marsalek is appointed COO.

The board of directors of a business corporation is responsible for developing CG policies and framework within which the corporation operates to serve the best interest of the 2015 The Financial Times (FT) raises questions aboucompany and shareholders. The CG framework should also inconsistencies in Wirecard's accounts. Wirecard takeoverensure that all business decisions are made ethically and are Indian payments businesses for $€ 340$ million.

2016 Anonymous short sellers report allegations related to money in compliance with regulations and laws. The board of laundering under the fictitious Zatarra. BaFin, the German directors typically establishes committees to help them financial regulator, investigates Zatarra and others for alleged perform their responsibilities. In the case of Wirecard, the market manipulation.

2017 EY issues a clean audit report. Markus Braun, CEO, borrows EO, borrows Supervisory Board members before filing for insolvency (end $€ 150$ million from Deutsche Bank in a margin loan secured with his $7 \%$ stock ownership in Wirecard.

March An internal whistleblower reports an allegation about the

2018 "round tripping" scheme to India.

April 2018 Daniel Steinboff, Head of Compliance in Munich, begins an investigation into three members of the finance team in Singapore.

September Wirecard replaces Commerzbank in the Dax 30 index, making 2018 it an automatic investment for pension funds around the world.

January FT reports the whistleblower's claims. BaFin begins the

2019 investigation on FT over an allegation of market manipulation.

Supervisory Board consists of six members. Table IV lists the of June 2020).

February BaFin announce

2019 Wirecard's stocks after the share price on short selling

Stefan Klestill (1)

Thomas Eichelmann (2)

Dr. Anastassia Lauterbach (3)

Vuyiswa V. M'Cwabeni

Susana Quintana-Plaza (4)

TABLE IV: SUPERVISORY BOARD OF WIRECARD

(1) Alfons W. Henseler resigned from the Supervisory Board effective June 18, 2019. Mr. Klestill became the new Deputy Chairman of the Supervisory Board as Mr. Henseler's successor.

April 2019 EY approves and issues Wirecard's 2018 financial reports (2) Mr. Eichelmann was elected to the Supervisory Board on June $18,2019$. $\begin{array}{ll}\text { with minor qualifications relating to Singapore. } & \text { (3) Tina Kleingarn stepped down from the Supervisory Board effective on }\end{array}$

October FT reports profits at Wirecard in Dubai and Dublin are inflated December 31, 2017. Dr. Anastassia Lauterbach joined the Supervisory Board

2019 with fictitious customers. Subsequently, Wirecard appoints as her successor on June 21, 2018.

$\begin{array}{ll}\text { KPMG to conduct an outside audit. } & \text { (4) Susana Quintana-Plaza joined the Supervisory Board effective on June }\end{array}$

December FT reports that Wirecard includes cash held in escrow 26, 2018.

2019 accounts managed by trustees in its cash balances on its Source: Wirecard AG 2018 Annual Report [21]. financial statements. EY receives documents appearing to be from a trustee in the Philippines that $€ 1.9$ billion is held in accounts at two banks in Philippines.

Based on Wirecard's CG report and CG statement issued April 28, KPMG discloses that they could not verify Wirecard's on March 29, 2018, the management and Supervisory Board
2020
revenue or cash are real since Senjo and other third parties declared that the Company had complied with the 2020 would not cooperater recommendations of the Government Commission German June 5, German prosecutors launch a criminal investigation against Corporate Governance Code (Code) with the following two 2020 Markus Braun, CEO, and three other executive board exceptions [20]:

June 16, The Philippine banks BPI and BDO inform EY that the 1. Supervisory Board committees (the Audit Committee, 2020 documents detailing $€ 1.9$ billion in balance are spurious. the Remuneration, Personnel and Nomination Committee, June 18, EY announces that $€ 1.9$ billion of cash balance is missing. and the Risk and Compliance Committee) were not formed $2020 \quad$ Wirecard's share price drops to $€ 30.90$ per share. Markus Braun, CEO, was forced to sell $€ 150$ million of shares in Wirecard due to his pledged loan. until the first quarter of 2019.

2. Wulf Matthais is both the Chairman of the Supervisory

June 19, Markus Braun resigns, and James Freis becomes the interim Board and the Chairman of the Audit Committee due to the

2020 CEO. $\quad$ special expertise and experience possessed by Mr. Matthais June 22, 2020

Wirecard admits that $€ 1.9$ billion of cash probably does not exist. Markus Braun, former CEO, turns himself in to German police. Jan Marsalek, COO, is fired. beginning in 2019.

Wirecard acquired InfoGenie, a young, internet-oriented June 23, Markus Braun, former CEO, is arrested on suspicion of false company listed in Germany in 2002 to gain public company $2020 \quad$ accounting and market manipulation.

June 25, Wirecard discloses to file for insolvency. Wirecard's share $2020 \quad$ price drops to $€ 3.53$ per share. Source: McCrum [13] status. Being a public listed company in Germany and subsequently joined the DAX 30 index in September 2018, the Supervisory Board committees, especially the Audit Committee and Nomination Committee, are necessary for the CG structure of Wirecard to effectively manage specific

\section{CORPORATE GOVERNANCE AND REGULATIONS}

The primary purpose of $\mathrm{CG}$ is to facilitate effective, entrepreneurial and prudent management that can deliver the long-term success of the company. Board of directors are responsible for the governance of their companies. Laws and regulations seek to protect investors by assuring the timely release of information and from loss due to illegal use of inside information and fraud in the company's financial issues that require specialized areas of expertise. The Supervisory Board committees are expected to provide the Company and its shareholders the benefit of strong accountability as Committee members have specific assigned tasks and are directly accountable to the full board for their completion.

In addition to the forming of committees, "Section 5.3.2 (3) Clause 3 of the Code recommends that the Chairman of 
the Supervisory Board should not also be the Chairman of the Audit Committee" [20]. Wirecard declared a divergence from Section 5.3.2. (3) Clause 3 of the Code as Wulf Mathias has been both the Chairman of the Supervisory Board and the Chairman of the Audit Committee beginning in the first quarter of 2019. The primary role of a company's Audit Committee is to provide oversight of the financial reporting process, the audit process, the company's system of internal controls, and compliance with laws and regulations. Wirecard, having Mr. Mathias as both the Chairman of the Supervisory Board and the Chairman of the Audit Committee, may limit the effectiveness of the Audit Committee to carry out its fiduciary duties and responsibilities. The absence of the Supervisory Board committees, especially the Audit Committee, in the CG structure of Wirecard prior to 2019 explains why the Supervisory Board failed to conduct their independent internal investigation of the several allegations relating to Wirecard's accounting practices much earlier in an effective and efficient manner, and thus failing to prevent management from manipulating earnings.

The second instance of failure of the Supervisory Board was preventing the inherent conflict of management's interest in permitting Markus Braun, CEO, to borrow $€ 150.0$ million from Deutsche Bank in a margin loan secured with his $7 \%$ stake in Wirecard in 2017, causing difficulty in achieving the goal of shareholder's wealth maximization. Many public company policies prohibit officers and directors from pledging their company shares against margin loans to prevent the conflicts of interest between shareholders and management. The conflict of interest lied in the fact that an officer of the company may have an incentive to boost the stock price in the short-term to avoid substantial losses from a forced sale to meet the terms of a personal margin loan. Additionally, an officer may call for company share buyback to boost the stock price for personal stock pledge reasons, which ultimately reduces shareholder value in the long-term. Moreover, the sale of the pledged shares by the lender is reportable by the insider and the sale could lead to insider trading charges where material inside information is involved [17]. As a result of the Supervisor Board's failure to prohibit Wirecard's former CEO from pledging the Company shares against his margin loan, Mr. Braun had the incentive to manipulate earnings and launched a share buyback program to boost the Company's stock price since the pledge. As soon as $E Y$ announced that $€ 1.9$ billion of cash balance was missing on June 18, 2020, Wirecard's share price dropped sharply to $€ 30.90$ per share, forcing Mr. Braun to sell $€ 150.0$ million of shares in Wirecard due to his margin loan. This course of action has further caused significant financial consequences for the Company and one of the factors leading the destruction of shareholders value.

\section{B. Outside Investors}

Outside investors including institutional investors play an important role in the CG of a business organization. Their interest is to promote the longer-term interests of the organization and ensure that the organization put shareholder interest over the interests of the managers. In the case of Wirecard, short sellers and SoftBank Group are the key outside investors significantly affected by the downfall of Wirecard.

\section{Short Sellers}

As stated by Leo Perry, co-runner of Ennismore Fund Management and short seller "what was really weird was how well documented it was" [9] and how little authorities did to investigate the allegations. However, after 12 years of betting against Wirecard, Perry is now "spectacularly vindicated yet still barely profiting from his work" [9] as the government finally seems to be looking straight into Wirecard's financials, and he is finally cashing in on his bets against Wirecard. In 2008, as part of his research into Wirecard's financials and following the attacks of the German Investor Association, Perry discovered that Wirecard's numbers did not add up "what they acquired wasn't worth very much;" "it was an obvious fraud because you worked back from the balance sheet and the assets..." [9], and even though he published his findings, Wirecard seemed immune to any criticism as it took five years since Perry's last published investigation, for Wirecard to come down from its glory.

Other short sellers, like Matthew Earl and Fraser Perring, also investigated Wirecard focusing their investigations on market manipulation and money laundering, but Wirecard again was able to stand its ground and avoid all allegations of mishandling. Today, we can say with certainty that short sellers played a significant role in the public dismay of Wirecard, as it was their investigative work that over the years allowed others, like the German government, to gain awareness of Wirecard's mishandling. The trueness in their work - their financial gain depends on the deep understanding of a company's finances - is what in the long run made them believable. It did not make sense that short sellers bet against a company that was performing so well worldwide. From our point of view, short sellers are the main reason the German government is now exploring the idea of legalizing third parties research and complaints as a trigger for a more indepth investigation of a public company's finances.

\section{SoftBank Group}

Unlike short-sellers, SoftBank Group seemed to deeply trust the leadership of Wirecard, and the position it had carved itself in the fintech industry worldwide. They saw Wirecard as a company with potential for growth and invested " $€ 900.0$ million in Wirecard through a convertible bond, providing a vital vote of confidence" [15] even after reports of insolvency were published on Wirecard. This investment was part of a "strategic cooperation agreement" [15] with Wirecard which was designed to impress and make everyone believe that "one of the world's most powerful technology investors was forging a deep business relationship with the German company and inspiring confidence in its shares" [15]. As part of the deal, Softbank agreed that their bond was to be paid with Company's stock. However, within a day of signing this agreement, Softbank "cut their exposure to the German payment group through the sale of new bonds exchangeable for the payments of Company's stock" [15]. The idea behind this move was to protect its original investment and still have the potential to earn profits as the stock increased its value over the coming years. Softbank's move made everyone wonder if they knew something about Wirecard's insolvency. Wirecard's stock price has plummeted since declaring 
insolvency in June 2020, fortunately for Softbank, "Credit Suisse's clients are bearing the huge losses" [15].

\section{External Auditors}

The primary role of external auditors in CG is to protect the interest of shareholders and evaluate the organization for compliance with regulations. The audit of the organization's financial statement increases the financial statements transparency and makes disclosures more accountable. While external auditors performed their audit of the organization's internal control over financial reporting, they help promote CG by conducting period risk assessment where financial fraud or errors could be occurring. External auditors also help to facilitate a more effective oversight of the financial reporting process by the board of directors by working with the audit committee and the company's internal auditors. In the case of Wirecard, EY failed in their fiduciary duties to protect all creditors and shareholders of Wirecard as they did not confirm directly with Singapore's OCBC Bank that the lender held large amounts of cash on behalf of Wirecard between 2016 to 2018 [18]. Instead, EY had issued unqualified audits of Wirecard during these years despite the increasing questions over suspected accounting irregularities from journalists and short sellers. Since EY failed to perform a proper audit procedure that could have uncovered the vast fraud at Wirecard between 2016 to 2018, EY is facing a classaction lawsuit in Germany brought by Wirecard investors and criminal complaints filed by Germany's small shareholder lobby group SdK.

\section{German Regulators}

Government regulations are the most effective external controls on the governance of a business organization. Agencies like Securities Exchange Commissions (SEC) in the United States (U.S.) and the Federal Financial Supervisory Authority (BaFin) in Germany are responsible for enforcing these regulations. BaFin is Germany's financial regulator over Germany's banks, financial services companies, insurance companies, stock exchanges, and other obligated institutions. BaFin's primary role is to ensure the stability and integrity of the German financial system including identifying and eliminating financial crime. This includes promoting anti-money laundering in Germany. BaFin reports directly to the German Federal Ministry of Finance. In the case of Wirecard, BaFin failed to adequately supervise Wirecard in the financial technology group as BaFin played down the allegations from investors, U.S. authorities, journalists, and employees of Wirecard. Instead, BaFin opened probes into the accusers. For example, when FT published its story on Wirecard's round tripping scheme in India involving third parties in January 2019, BaFin opened its investigation into FT over an allegation of market manipulation. BaFin further banned investors from shorting Wirecard's stock citing "Wirecard's importance for the economy and the serious threat to market confidence" [13]. It is difficult to understand why for over 12 years BaFin disregarded every single public allegation of fraud and money laundering against Wirecard. Instead of investigating claims against Wirecard itself, BaFin asked the Financial Reporting Enforcement Panel (FREP), a small private-sector body, to audit Wirecard's accounts. However, only one auditor at FREP was assigned to the Wirecard case and little progress was made [7]. The inability of FREP to complete the audit of
Wirecard and uncover the vast fraud raised our concerns about Germany's ability to enforce securities rules that protect investors. According to a spokeswoman of BaFin, the supervisory role BaFin plays in the German economy all because the agency claims to be "an administrative authority and not a law enforcement agency" [7].

Germany has an inconsistent record in fighting corporate crime. The Volkswagen emissions cheating scandal and Deutsche Bank allegation of money-laundering - both discovered and sanctioned by two different American regulatory agencies - certainly creates distrust in the eyes of the investors and public in general. However, it becomes exponential when adding Wirecard to the equation and the years it took for BaFin to finally act on the different accusations brought up by the American regulators, short sellers, investors, employees, and journalists [7]. Ironically history repeated itself, as BaFin only investigated Wirecard after an American regulatory agency denounced Wirecard twice for fraudulent monetary transactions and moneylaundering. What does this say about either country's regulatory agencies? Can we only trust American regulators? What is it about the American regulation system that seems to work better than the German?

After the fallout of Wirecard, exposed BaFin documentation showed that "BaFin, saw Wirecard's former CEO as more trustworthy than his critics because he bought a large chunk of shares in the Company at a key moment" [7]. This is an interesting but completely unreliable measuring tool on assessing a company's worldwide performance and trustworthiness. Instead, BaFin turned against many of the accusers who legitimately raised concerns about the Company's financials, and instead started criminal investigations against them due to possible market manipulation. Shouldn't BaFin have brought the FREP on board to serve as the agency supervising the audit reports produced by KPMG before sending people to jail? Shouldn't the German courts also raise a flag on this? Should the German government allow for flexibility in what BaFin picks to oversee or not oversee? The key to this is for the German government to establish more checks and balances by allowing for additional audit overseeing agencies like Public Company Accounting Oversight Board (PCAOB) in the U.S. to oversee public companies audits in order to protect investor's interest, and trustworthiness of companies at stake. Further, they should also eliminate flexibility in what a regulatory agency chooses to regulate, eliminating any gray areas there could be.

\section{MANAGEMENT AND SUPERVISORY BOARD COMPENSATION STRUCTURE}

The compensation structure for the Management Board consists of fixed and variable components, while the compensation structure for the Supervisory Board consists of a fixed component.

\section{A. Compensation Structure of the Management Board}

The following Table V summarizes the key components of the compensation structure of the Management Board in fiscal 2018: 
TABLE V: COMPENSATION STRUCTURE

\begin{tabular}{|c|c|c|c|c|}
\hline Structure & & Performance Criteria & Allocation & Target 2018 \\
\hline \multirow{11}{*}{ Performance } & \multicolumn{4}{|c|}{ Multi-Year Variable Compensation } \\
\hline & Term: & Three years & & \\
\hline & \multirow{3}{*}{ Performance targets: } & EBITDA growth & $33 \%$ & $20 \%$ growth \\
\hline & & Stock performance & $33 \%$ & $15 \%$ growth \\
\hline & & TSR relative to TecDAX & $33 \%$ & $20 \%$ growth \\
\hline & \multirow[t]{2}{*}{ Cap: } & Payment limited to $150 \%$ of target bonus value & & \\
\hline & & \multicolumn{3}{|l|}{ Single-Year Variable Compensation } \\
\hline & \multirow{3}{*}{$\begin{array}{c}\text { Term: } \\
\text { Performance target: }\end{array}$} & One year & \multirow{4}{*}{$\begin{array}{l}50 \% \\
50 \%\end{array}$} & \multirow{4}{*}{$\begin{array}{l}20 \% \text { growth } \\
15 \% \text { growth }\end{array}$} \\
\hline & & EBITDA growth & & \\
\hline & & Stock performance & & \\
\hline & Cap: & Payment limited to $150 \%$ of target bonus value & & \\
\hline \multirow{3}{*}{$\begin{array}{l}\text { Non- } \\
\text { Performance }\end{array}$} & Base compensation: & Annual sum, paid as monthly salary & & \\
\hline & Fringe benefits: & E.g., company car, travel costs, other & & \\
\hline & Retirement benefits: & $\begin{array}{l}\text { Fixed contribution to private retirement } \\
\text { benefits }\end{array}$ & & \\
\hline
\end{tabular}

Source: Wirecard AG 2018 Annual Report [19].

MVR covers a period of three years and is calculated on the basis of the above three equally weighted performance targets. The Total Shareholder Return (TSR) measures the growth in value of the Company for its shareholders and it takes into account dividends and the share price performance over a 3-year period.

SVR is structured as a performance bonus and is paid at the end of the fiscal year, subject to the achievement of the underlying targets. The performance criteria include EBITDA growth and the share price performance of the Company. The SVR comprised approximately $40 \%$ of the performance-based compensation in fiscal 2018. Table VI summarizes the compensation of the Management Board for fiscal 2018 and 2017 (in Euros and thousands):

\begin{tabular}{|c|c|c|c|c|c|c|c|c|c|c|}
\hline \multirow{2}{*}{$\begin{array}{l}\text { Compensation } \\
\text { Structure }\end{array}$} & \multicolumn{2}{|c|}{$\begin{array}{l}\text { Markus Braun } \\
\text { CEO }\end{array}$} & \multicolumn{2}{|c|}{$\begin{array}{c}\text { Alexander Knoop } \\
\text { CFO }\end{array}$} & \multicolumn{2}{|c|}{$\begin{array}{l}\text { Burkhard Ley } \\
\text { (Former CFO) }\end{array}$} & \multicolumn{2}{|c|}{$\begin{array}{c}\text { Jan Marsalek } \\
(\mathrm{COO})\end{array}$} & \multicolumn{2}{|c|}{$\begin{array}{c}\text { Susanne Steidl } \\
\text { (CPO) }\end{array}$} \\
\hline & FY18 & FY17 & FY18 & FY17 & FY18 & FY17 & FY18 & FY17 & FY18 & FY17 \\
\hline Non-Performance: & & & & & & & & & & \\
\hline Based & 1,600 & 1,350 & 736 & - & - & 1,000 & 1,025 & 900 & 736 & - \\
\hline Benefits & 526 & 478 & 223 & - & - & 43 & 325 & 303 & 209 & - \\
\hline $\begin{array}{l}\text { Total non- } \\
\text { performance }\end{array}$ & 2,126 & 1,828 & 959 & - & - & 1,043 & 1,350 & 1,203 & 945 & - \\
\hline $\begin{array}{l}\% \text { total } \\
\text { compensation }\end{array}$ & $61 \%$ & $77 \%$ & $90 \%$ & - & - & $58 \%$ & $49 \%$ & $68 \%$ & $96 \%$ & - \\
\hline Performance-based: & & & & & & & & & & \\
\hline SVR & 798 & - & 110 & - & - & - & 768 & - & 35 & - \\
\hline MVR & 561 & 561 & - & - & - & 761 & 612 & 561 & - & - \\
\hline Total performance & 1,359 & 561 & 110 & - & - & 761 & 1,380 & 561 & 35 & - \\
\hline $\begin{array}{c}\% \text { total } \\
\text { compensation }\end{array}$ & $39 \%$ & $23 \%$ & $10 \%$ & - & - & $42 \%$ & $51 \%$ & $32 \%$ & $4 \%$ & - \\
\hline Total compensation & 3,485 & 2,389 & 1,069 & - & - & 1,804 & 2,730 & 1,764 & 980 & - \\
\hline
\end{tabular}

Source: Wirecard AG 2018 Annual Report [19].

As noted in Table VI, the performance-based compensation represents $35 \%$ and $27 \%$ of the total compensation of the Management Board in fiscal 2018 and 2017, respectively. The main corporate objective of linking the compensation of the Management Board to the performance of the Company's share price and TSR is to provide an incentive to sustainably increase the shareholder value of the Company over the long term. With the absence of a clawback provision in the Management Board's performance-based compensation agreement, this compensation structure failed to achieve such goal. Instead, it provided an incentive to management to manipulate earnings to achieve the underlying targets in order to compensate for business growth that otherwise would have not met the Street's expectations. Additionally, as a result of a large number of years of continued growth of the stock price, Wirecard created significant wealth in the market during those years, reaching a market cap of approximately $\$ 28.0$ billion. As a result, management was under heavy market pressure to continue showing a business growth consistent with historical trends. Fig. 7 reflects the stock performance since Markus Braun, CEO, joined the Management Board in October 2004 through July 2020.

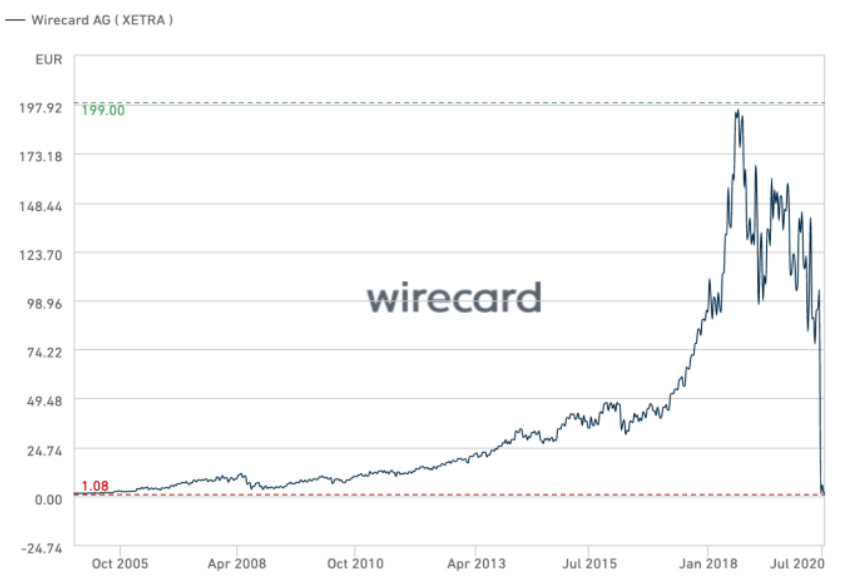

Fig. 7. The stock performance since Markus Braun, CEO, joined the Management Board. Source: Wirecard's corporate website, Investor Relations. 


\section{B. Compensation Structure of the Supervisory Board}

The compensation of the Supervisory Board consists of a fixed compensation structure (non-performance based). Table VII summarizes the compensation of the Supervisory Board in fiscal 2018 and 2017 (in thousands):

\begin{tabular}{|c|c|c|c|}
\hline Name & Title & FY 2018 & FY 2017 \\
\hline Wulf Matthias & Chairman & $€ 316$ & $€ 319$ \\
\hline Alfons W. Henseler & $\begin{array}{c}\text { Deputy } \\
\text { Chairman }\end{array}$ & $€ 251$ & $€ 254$ \\
\hline Stefan Klestil & Member & $€ 186$ & $€ 188$ \\
\hline Tina Kleingarn & Member & - & $€ 135$ \\
\hline Vuyiswa V. M'Cwabeni & Member & $€ 131$ & $€ 135$ \\
\hline $\begin{array}{c}\text { Dr. Anastassia } \\
\text { Lauterbach }\end{array}$ & Member & $€ 65$ & - \\
\hline Susana Quintana-Plaza & Member & $€ 65$ & - \\
\hline
\end{tabular}

Tina Kleingarn resigned at the end of fiscal 2017 for personal reasons. Two new members, Dr. Anastassia Lauterbach and Susana Quintana-Plaza, joined the Supervisory Board in 2018. As a result, the Supervisory Board had an equal number of male and female members in 2018.

\section{CONCLUSION}

The collapse of Wirecard was caused by a fraud scheme that became so large that bankruptcy was inevitable. There are several factors that contributed to the creation, development and evolution of this fraud scheme. We believe that among the main factors leading to this outcome are significant pressure over management to meet the Street's expectations and management's consensus from a business that was growing organically below expectations. As a result, management continued using artificial revenue and/or inflated earnings to make up for the difference to meet expectations [4]-[6] and [22]. This is a clear situation of misalignment of interests between management and shareholders.

The key mitigation controls to prevent the existence of fraud consisted of CG executed by the Board of Directors (through their Committee meetings with management, review of significant transactions and financial information) and the external auditors (through the verification of the completeness, existence, and accuracy of the Company's financial statements). However, both controls failed, creating a favorable environment for management for executing a fraud scheme for several years.

While regulations do implement certain measures to reduce the accounting malpractice, the real issue is management's incentive to commit fraud. Laws and regulations may limit the opportunity to commit fraud but ultimately, they cannot completely control the behavior from fraudulent management. The importance of ethical behavior cannot be overemphasized [22].

Most likely, the relevant authorities of Germany and other European countries will need to reform the current financial regulation of fintech to strengthen their CG system. Similar to other corporate frauds that ends the Company filing for bankruptcy, the real losers are Wirecard's employees, creditors, and its shareholders, who bear substantial losses.

\section{REFERENCES}

[1] Jo, H. \& Harjoto, M. (2011). Corporate governance and firm value: the impact of corporate social responsibility, Journal of Business Ethics, 103, 351-383.

[2] Jensen, M. (1993). The modern industrial revolution, exit, and the failure of internal control systems, Journal of Finance 48, 831-880.

[3] Miller, M. (2005). Is American corporate governance fatally flawed? In D. Chew and S. Gillan (eds.), Corporate Governance at the Crossroads: A Book of Readings (Irwin Mcgraw-Hill, Boston, MA)

[4] Dossani, A., \& Jo, H. (2010). Corporate governance and the fall of Enron, Review of Business Research, 3, 13-24

[5] Jo, H., Kim, Y., \& Park, M. (2007). Underwriter choice and earnings management: Evidence from seasoned equity offerings. Review of Accounting Studies, 12, 23-59.

[6] Jo, H. \& Kim, Y. (2007). Disclosure frequency and earnings management. Journal of Financial Economics, 84, 561-590.

[7] Fairless, T., Kowsmann, P., \& Davies, P. (2020). How Germany's SEC dismissed a decade of warnings about Wirecard, The Wall Street Journal. Available: https://www.wsj.com/articles/how-germanys-secdismissed-a-decade-of-warnings-about-wirecard11594907212 ?st=qtys $2415 \mathrm{ye} 0 \mathrm{~g} 6 \mathrm{gg} \& \mathrm{reflink}=$ article_email_share.

[8] Healy, P.M (1985). The effect of bonus schemes on accounting decisions. Journal of Accounting and Economics 7, 85-107.

[9] McCrum, D. (2020). Wirecard: the timeline. Financial Times. Available: https://www.ft.com/content/284fb1ad-ddc0-45df-a075$0709 \mathrm{~b} 36868 \mathrm{db}$.

[10] Meitner, V. (2020). Wirecard's thrilla in Manila: the story so far (1), Valuesque. Available: https://valuesque.com/2020/06/20/wirecardsthrilla-in-manila-the-story-so-far-1/.

[11] KPMG AG (2020). KPMG report concerning the independent special investigation.

[12] Davies, Paul J. (2020). How Wirecard went from tech star to bankrupt. Wall Street Journal.

Available:https://www.wsj.com/articles/wirecard-bankruptcy-scandalmissing-\$2billion-11593703379.

[13] McCrum, D. (2020). Wirecard made this short seller right, but not rich, Financial Times. Available: https://www.ft.com/content/ecc $4 \mathrm{f} 12 \mathrm{f}-$ 9c3a-412f-92d1-eba810a6fb9b

[14] Bender R. \& Davies, Paul. (2020). Wirecard's Markus Braun is arrested again as scandal embroils Angela Merkel. Wall Street Journal. Available: https://www.wsj.com/articles/german-prosecutors-expandcase-against-former-wirecard-executives-11595432184.

[15] Massoudi, A. \& Smith, R. (2020). SoftBank executives set to lose profits from Wirecard trade, Financial Times. Available: https://www.ft.com/content/b8eec9d0-0c85-467d-8cb1-467ad87adce.

[16] McCrum, D., \& Palma, S. (2019). Wirecard: inside an accounting scandal, Financial Times. Available: https://www.ft.com/content/d51a012e-1d6f-11e9-b126-46fc3ad87c65.

[17] Posner, Cydney (2016). Should insiders be permitted to pledge their company shares? Cooley Pubco. Available: https://cooleypubco.com/2016/01/31/should-insiders-be-permitted-topledge-their-company-shares/.

[18] Storbeck, O., Kinder, T. \& Palma, S. (2020). EY failed to check Wirecard bank statements for 3 years. Financial Times. Available: https://www.ft.com/content/a9deb987-df70-4a72-bd4147ed8942e83b.

[19] Wirecard AG (2019). 2018 Annual Report. Available: https://ir.wirecard.com/download/companies/wirecard/Annual\%20Re ports/DE0007472060-JA-2018-EQ-E-01.pdf.

[20] Wirecard AG (2019). 2019 Corporate Governance Report and Corporate Governance Statement. Available: https://ir.wirecard.com/download/companies/wirecard/Hauptversamm lung/18_EN_Corporate_GovernanceReport.pdf.

[21] Wirecard AG (2019). Half year financial report as of 30 June 2019 Available: https://ir.wirecard.com/download/companies/wirecard/Quarterly\%20 Reports/DE0007472060-Q2-2019-EQ-E-00.pdf.

[22] Jo, H. \& Kim, Y. (2008). Ethics and disclosure: A study of the financial performance of firms in the seasoned equity offering market, Journal of Business Ethics, 80(4), 855-878. 


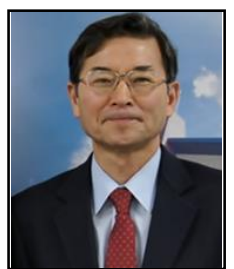

Hoje Jo earned his PhD in finance at the University of Florida in 1986 and is currently the Gerald and Bonita Wilkinson Professor of Finance at the Leavey School of Business, Santa Clara University. Jo has published more than ninety refereed articles in various journals including the Journal of Finance, Journal of Financial Economics, and Journal of Business Venturing among others. Jo's current research interests include corporate governance, corporate social responsibility (CSR), organizational sustainability, environmental responsibility, and ethics in finance, Jo is a special issue editor of "Ethics and Finance" for the Global Finance Journal and Asia-Pacific Journal of Financial Studies, and currently serves on the editorial boards of the Asian Journal of Sustainability and Social Responsibility.

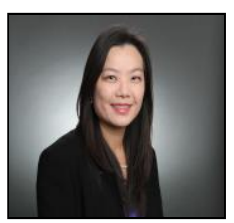

Annie Hsu earned her MBA in finance from Santa Clara University, Leavey School of Business, in 2020 She earned her Bachelor of Science in business administration with accounting concentration from University of California Berkeley, Haas School of Business, in 1999. She has provided financial accounting and reporting consulting services to Novi Financial, Inc., a subsidiary of Facebook, Inc., in Menlo Park, California since March 2021. From May 2002 to March 2018, she held various positions with Super Micro Computer, Inc., a global provider in enterprise computing, storage, networking solutions, and green computing technology headquartered in San Jose, California, where for the last two and a half years she served as Sr. Director of Financial Reporting and Planning. From September 1999 to May 2002, she served various positions within the assurance practice at Arthur Andersen, LLP, a global professional service firm, where for the last one year she served as Audit Senior of Assurance Services. She is a Certified Public Accountant (CPA) of the State of California and a member of the American Institute of Certified Public Accountants (AICPA). She is also a member of the Beta Gamma Sigma, The International Business Honor Society, under Santa Clara University chapter.

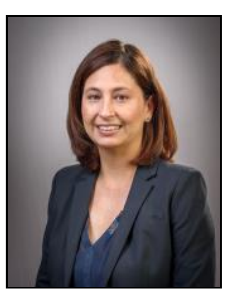

Rosamaria Llanos-Popolizio earned her MBA in finance from Santa Clara University, Leavey School of Business, in 2020. She earned her Bachelor of Art in Architecture from University of California Berkeley in 2006. She has held various positions as a project manager for high-end residential architecture firms in California and is currently employed at City of San Jose where she manages the design and construction of Capital Improvement Projects (CPI). Rosamaria has successfully completed her National Council of Architectural Registration Board Internship, is a member of the American Institute of Architecture, and is preparing to undergo examination and obtain a professional license in architecture in the state of California. Rosamaria's financial interests are in Social Corporate Responsibility, Environmental Responsibility, and Commercial Real Estate.

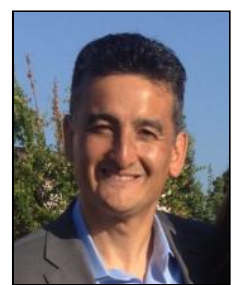

Jorge Vergara-Vega earned his MBA in finance from Santa Clara University, Leavey School of Business, in 2020. He earned his undergraduate degree in Accounting and Business Administration from the University of Concepción, Chile, in 1990 and 1994, respectively. He currently serves as Senior Director of External Financial Reporting and Technical Accounting at Zscaler, Inc., a cloud-based information security company headquartered in San Jose, California, since 2017. From 2013 to 2017, he served as Senior Manager of External Financial Reporting and Technical Accounting at Aruba Networks, a Hewlett Packard Enterprise company, a wireless and security networking company. From 2009 to 2013, he provided a mix of financial accounting consulting services and full-time roles at various technology companies headquartered in the Silicon Valley. From July 1993 to March 2009, he served various positions within the assurance practice at PricewaterhouseCoopers LLP, a multinational professional services firm, where for the last four years he served as Senior Manager of Assurance Services. Mr. Vergara-Vega is a Certified Public Accountant (CPA) of the State of California and a member of the American Institute of Certified Public Accountants (AICPA). 